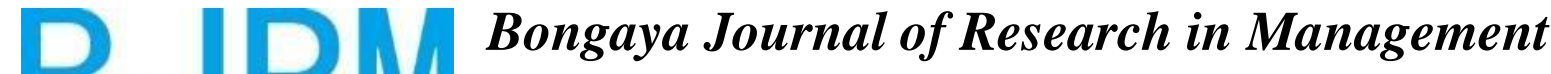

Volume 1 Nomor 2. Hal 01-08. e-ISSN: 2615-8868

Homepage: https://ojs.stiem-bongaya.ac.id/index.php/BJRM

\section{MEWUJUDKAN KEBERHASILAN KERJA MELALUI PERSEPSI LOCUS OF CONTROL INDIVIDU KARYAWAN SEMEN BUMN}

\author{
Andi Ririn Oktaviani ${ }^{1)}$ \\ ${ }^{1}$ Manajemen,STIE Nobel Indonesia \\ Email: rhien_octaviany@yahoo.co.id
}

(Diterima: 20 Agustus 2018; direvisi: 18 September 2018; dipublikasikan: 31 Oktober 2018 )

(7) (5) (2018 -Bongaya Journal of Research in Management STIEM Bongaya. Ini adalah artikel dengan akses terbuka dibawah licenci CC BY-NC-4.0 (https://creativecommons.org/licenses/by-nc/4.0/ ).

\begin{abstract}
This study aims to identify perceptions of attitudes of cement employees of BUMN in carrying out work to achieve job success. The method for collecting data in this study uses questionnaires and interviews and analysis techniques with structural equation models (SEM). The results of this study indicate that the tendency of internal locus of control owned by most cement employees of BUMN plays an important role as an employee work stimulus to succeed in his job.
\end{abstract}

Keywords: Locus of Control; Job Success.

\begin{abstract}
Abstrak: Penelitian ini bertujuan mengidentifikasi persepsi kecenderungan sikap karyawan semen BUMN dalam melaksanakan pekerjaan untuk mencapai keberhasilan kerja.Metode untuk mengumpulkan data dalam penelitian ini menggunakan kuesioner dan wawancara dan teknik analisis dengan model persamaan struktural (SEM). Hasil penelitian ini menunjukkan bahwa kecenderungan locus of control internal yang dimiliki sebagian besar karyawan semen BUMN berperan penting sebagai stimulus kerja karyawan untuk berhasil dalampekerjaannya.
\end{abstract}

\section{Kata Kunci: Locus of Control; Keberhasilan Kerja.}

\section{PENDAHULUAN}

Locus of Control (LOC) sebagai konstruksi kepribadian pada tiap individu karyawan yang stabil dan mendasari karakteristik perubahan sikap dan keyakinan untuk mencapai tujuan karir yang diinginkannya.LOCdipersepsikan sebagai keyakinan individu karyawan yang perlu dipertimbangkan dan menjadi perhatian manajemen perusahaan karena terkait erat dengan kepercayaan diri tertinggi pada diri karyawan atas kontrol, kemandirian dan kegigihan untuk memenuhi tanggung jawab pekerjaan dan berorientasi pada pencapaian keberhasilan kerja sesuai yang dipersyaratkan perusahaan.

Beberapa kajian LOC yang dilakukan peneliti-peneliti sebelumnya menunjukkan bahwa terdapat perbedaan konseptual dalam pembentukan teori, perbedaan budaya, dan konstruk terkait perspektif LOC internal atau LOC eksternal yang dominan berpengaruh terhadap keberhasilan kerja individu karyawan(Biondo \& MacDonald, 1971); (Marks, 1998); (Martin, Thomas, Charles, Epitropaki, \& McNamara, 2005); (K. April, Dharani, \& Peters, 2011).

Adanya fakta bahwa dunia itu dinamis dan berubah menciptakan 
tantangan bagi perusahaan. Manusia selalu seperti perubahan di alam semesta ini tetapi kecepatan perubahan menuntut semua pihak yang terkait dalam perusahaan untuk menampilkan performa kerja yang tinggi. Beberapa hasil penelitian menunjukkan perbedaan terkait kecenderungan LOC pada tiap individu yang mempengaruhi pencapaian keberhasilan kerja, antara lain: (K. A. April, Dharani, \& Peters, 2012) yang menyimpulkan bahwa tingkat maksimum kebahagiaan atas keberhasilan kerja dicapai oleh individu dengan LOC seimbang yaitu perpaduan LOC internal dan LOC eksternal atau dikenal sebagai ' $b i$ local expectancy', sementara (Pannells \& Claxton, 2008) dan (Schnitzlein \& Stephani, 2016) menyebutkan kriteria pemenuhan intrinsik dan keseimbangan kehidupan kerja, serta LOC internal secara positif meramalkan kemampuan dan membuktikan bahwa keberhasilan kerja yang tinggi dicapai oleh individu dengan kecenderungan LOC internal. Hal ini bertentangan dengan beberapa literatur akademis Barat yang menyimpulkan bahwa tingkat keberhasilan yang lebih tinggi dicapai oleh individu dengan LOC eksternal.

\section{METODE}

Metode yang digunakan untuk mengumpulkan data dalam penelitian ini menggunakan kuesioner dan wawancara dengan pola eksplanasi yang bermaksud menjelaskan kedudukan variabel-variabel yang diteliti serta hubungan antara satu variabel dengan variabel lain. Dalam explanatory dilakukan dalam dua tahap, pada tahap pertama lebih menekankan pada pengumpulan dan analisis data kuantitatif kemudian dilanjutkan dengan pendekatan kualitatif untuk menggambarkan atau menjelaskan lebih lanjut temuan kuantitatif (Lodico, Spaulding, \& Voegtle; 2006).

Populasi dalam penelitian ini adalah seluruh karyawan organik atau tetap PT Semen Indonesia, PT Semen Padang, PT Semen Tonasa, dan PT Semen Gresik berjumlah 5.122 orang karyawan.Teknik pengambilan sampel menggunakan teknik quota sampling yang dapat memastikan bahwa kelompok tertentu secara memadai terwakili dalam penelitian melalui penggunaan kuota berjumlah 399 orang karyawan.

Jenis penelitian ini dapat digolongkan sebagai penelitian dasar (fundamental research). Teknis analisa yang digunakan untuk menganalisis data adalah analisis structural equation model (SEM).

\section{HASIL DAN PEMBAHASAN}

\section{Hubungan antara locus of control} (LOC) dan berbagai reaksi yang berhubungan dengan keberhasilan pekerjaan misalnya kepuasan kerja intrinsik atau ekstrinsik, kesejahteraan terkait pekerjaan, dan komitmen organisasi, hubungan kualitas yang lebih baik dengan rekan kerja dan atasan serta pihak lain yang terkait dalam lingkungan perusahaanyang mempengaruhi persepsi atau keyakinan individu untuk melakukan pekerjaan dengan bersungguh-sungguh dan kerja keras. LOC internal dalam penelitian ini adalah keyakinan bahwa setiap individu karyawan perusahaan semen BUMN memiliki tanggung jawab dan peran atas keberhasilan diri sendiri dengan 5 indikator (suka bekerja keras, memiliki inisiatif yang tinggi, selalu berusaha untuk menemukan pemecahan masalah, selalu mencoba untuk berfikir seefektif mungkin, dan selalu mempunyai persepsi bahwa usaha harus dilakukan jika ingin berhasil). Sedangkan LOC eksternal dalam penelitian ini adalah individu karyawan perusahaan semen BUMN yang mempercayai bahwa perilaku kerja dan keberhasilan tugas mereka lebih dikarenakan faktor di luar diri yaitu organisasi dengan 4 indikator (kurang memiliki inisiatif, mempunyai harapan bahwa ada sedikit korelasi antara usaha 
dan kesuksesan, kurang suka berusaha karena percaya bahwa faktor luarlah yang mengontrol, dan kurang mencari informasi untuk memecahkan masalah).

Tabel 4.1. Deskripsi Variabel Locus of ControlInternal

\begin{tabular}{|c|c|c|c|c|c|c|c|c|c|c|c|}
\hline \multirow[t]{3}{*}{ Indikator } & \multicolumn{10}{|c|}{ Skor Jawaban Responden } & \multirow[t]{3}{*}{ Rerata } \\
\hline & \multicolumn{2}{|c|}{1} & \multicolumn{2}{|c|}{2} & \multicolumn{2}{|c|}{3} & \multicolumn{2}{|c|}{4} & \multicolumn{2}{|c|}{5} & \\
\hline & $\mathrm{F}$ & $\%$ & $\mathrm{~F}$ & $\%$ & $\mathrm{~F}$ & $\%$ & $\mathrm{~F}$ & $\%$ & $\mathrm{~F}$ & $\%$ & \\
\hline $\begin{array}{l}\text { Suka bekerja } \\
\text { keras (X2.1) }\end{array}$ & 1 & 0,3 & 12 & 3,5 & 79 & 23,3 & 181 & 53,4 & 66 & 19,5 & 3,88 \\
\hline $\begin{array}{l}\text { Memiliki inisiatif } \\
\text { yang tinggi } \\
\text { (X2.2) }\end{array}$ & - & - & 4 & 1,2 & 49 & 14,5 & 216 & 63,7 & 70 & 20,6 & 4,04 \\
\hline $\begin{array}{l}\text { Selalu berusaha } \\
\text { menemukan } \\
\text { pemecahan } \\
\text { masalah (X2.3) }\end{array}$ & - & - & 1 & 0,3 & 42 & 12,4 & 217 & 64,0 & 79 & 23,3 & 4,10 \\
\hline $\begin{array}{l}\text { Selalu mencoba } \\
\text { berfikir seefektif } \\
\text { mungkin (X2.4) }\end{array}$ & - & - & - & - & 18 & 5,3 & 227 & 67,0 & 94 & 27,7 & 4,22 \\
\hline $\begin{array}{l}\text { Selalu } \\
\text { mempunyai } \\
\text { persepsi usaha } \\
\text { harus dilakukan } \\
\text { jika ingin berhasil } \\
\text { (X2.5) }\end{array}$ & - & - & - & - & 17 & 5,0 & 187 & 55,2 & 135 & 39,8 & 4,35 \\
\hline & & & & & & & & & & Mean & 4,12 \\
\hline
\end{tabular}

Sumber: Data Olahan (2018)

Tabel 4.1. menunjukkan rata-rata skor jawaban responden untuk variabel locus of control (LOC) internal adalah sebesar 4,12dengan indikator tertinggi selalu mempunyai persepsi bahwa usaha harus dilakukan jika karyawan ingin meraih keberhasilan (X2.5) yang dicirikan adanya keyakinan bahwa keberhasilan akan dicapai jika karyawan bersungguhsungguh melaksanakan tugas dan tanggung jawab yang diembannya. Indikator selanjutnya selalu mencoba berfikir seefektif mungkin (X2.4) dengan ciri kecenderungan individu dengan LOC internal akan membuat karyawan selalu berusaha melaksanakan pekerjaan dengan pertimbangan yang matang dan secara efektif sehingga dapat menunjukkan kinerja tinggi yang memenuhi prasyarat penilaian kinerja karyawan. Indikator tertinggi ketiga adalah selalu berusaha menemukan pemecahan masalah (X2.3) dengan ciri sebagian besar karyawan memiliki sikap cenderung LOC internal dengan selalu berusaha untuk mengatasi masalah atau konflik yang dapat timbul dalam lingkungan kerja dan karyawan memiliki keyakinan yang cukup tinggi atas kemampuan dan potensi yang dimilikinya sehingga permasalahan apapun yang terjadi dalam lingkungan kerja dapat diselesaikan secara baik. Hal tersebut merupakan salah satu tolok ukur penilaian kompetensi kepemimpinan karyawan jenjang eselon jabatan 1 sampai dengan 4 dengan kualifikasi problem solving.Selain itu, terdapat 1 orang atau sebesar $0,3 \%$ responden yang memilih jawaban tidak setuju atas pernyataan pada indikator ini. Penyebabnya dapat diidentifikasi 
dipengaruhi oleh kondisi dalam struktur organisasi besar seperti di perusahaan semen BUMN dengan unit kerja yang banyak dan beragam, rentan terjadi konflik atau kesalahpahaman antar satu individu karyawan dengan individu karyawan lainnya dan hal tersebut dapat menurunkan semangat karyawan untuk menampilkan kinerja kerja yang dipersyaratkan perusahaan.

Kecenderungan LOC internal karyawan selanjutnya ditunjukkan pada indikator memiliki inisiatif yang tinggi (X2.2) dengan ciri LOC internal akan membuat karyawan memiliki inisiatif yang tinggi dalam bekerja. Hal ini sejalan dengan apa yang dikemukan oleh (Kreitner \& Kinicki, 2009:p154), yang menyatakan bahwa individu dengan LOC internal memiliki keyakinan untuk mengendalikan segala peristiwa dan konsekuensi yang memberikan dampak pada hidup mereka. Indikator ini juga ada yang ditanggapi dengan jawaban tidak setuju sebanyak 4 orang atau $1,2 \%$ responden karena dipengaruhi persepsi bahwa standar atau prosedur pekerjaan yang selama ini dilaksanakan merupakan karakteristik tugas yang rutin dan telah baku dilakukan tanpa perlu inisiatif untuk memodifikasi ke cara kerja yang lebih efektif. Indikator selanjutnya adalah suka bekerja keras (X2.1) yang dicirikan sebagian besar karyawan giat dalam bekerja. Keyakinan dan sikap karyawan untuk selalu bekerja keras dan berusaha menyelesaikan pekerjaan yang diberikan pada akhirnya akan diapresiasi oleh atasan dan memberikan reward sesuai dengan pencapaian karyawan secara personal maupun dalam unit kerja di perusahaan. Namun, ada juga responden yang menanggapi pernyataan-pernyataan dalam indikator ini dengan pilihan jawaban sangat tidak setuju sebanyak 1 orang atau $0,3 \%$ responden dan tidak setuju sebanyak 12 orang atau $3,5 \%$ responden. Hal ini dapat dideskripsikan bahwa di perusahaan semen BUMN, ada karyawan yang bekerja keras hanya karena keinginan mengharapkan imbalan sebagai pendorong dalam melaksanakan pekerjaan yang diberikan atasan. Meskipun demikian, hal ini dapat bermakna positif karena karyawan tersebut walaupun dilatarbelakangi dengan persepsi dorongan motivasi yang berbeda dibandingkan mayoritas karyawan lainnya tetapi tetap diapresiasi karena pada prinsipnya juga berupaya melaksanakan tanggungjawab pekerjaan yang diembannya. Hasil temuan atas tanggapan responden terkait indikator ini sejalan dengan pendapat (Rotter, 1966) yang mengemukakan bahwa LOC internal mengacu pada orang-orang yang percaya bahwa hasil, keberhasilan dan kegagalan mereka sebagai implikasi dari tindakan dan hasil usaha mereka sendiri.

Tabel 4.2. Deskripsi Variabel Locus of ControlEksternal

\begin{tabular}{|c|c|c|c|c|c|c|c|c|c|c|c|}
\hline \multirow[t]{3}{*}{ Indikator } & \multicolumn{10}{|c|}{ Skor Jawaban Responden } & \multirow[t]{3}{*}{ Rerata } \\
\hline & \multicolumn{2}{|c|}{1} & \multicolumn{2}{|c|}{2} & \multicolumn{2}{|c|}{3} & \multicolumn{2}{|c|}{4} & \multicolumn{2}{|c|}{5} & \\
\hline & $\mathrm{F}$ & $\%$ & $\mathrm{~F}$ & $\%$ & $\mathrm{~F}$ & $\%$ & $\mathrm{~F}$ & $\%$ & $\mathrm{~F}$ & $\%$ & \\
\hline $\begin{array}{l}\text { Kurang memiliki } \\
\text { inisiatif (X2.6) }\end{array}$ & 2 & 0,6 & 46 & 13,6 & 110 & 32,4 & 166 & 49,0 & 15 & 4,4 & 3,43 \\
\hline $\begin{array}{l}\text { Mempunyai } \\
\text { harapan bahwa } \\
\text { ada sedikit } \\
\text { korelasi antara } \\
\text { usaha dan } \\
\text { kesuksesan } \\
\text { (X2.7) }\end{array}$ & 9 & 2,7 & 90 & 26,5 & 117 & 34,5 & 103 & 30,4 & 20 & 5,9 & 3,10 \\
\hline Kurang suka & 33 & 9,7 & 113 & 33,3 & 95 & 28,0 & 81 & 23,9 & 17 & 5,0 & 2,81 \\
\hline
\end{tabular}




\begin{tabular}{|l|c|c|c|c|c|c|c|c|c|c|c|}
\hline $\begin{array}{l}\text { berusaha karena } \\
\text { percaya bahwa } \\
\text { faktor luarlah } \\
\text { yang mengontrol } \\
\text { (X2.8) }\end{array}$ & & & & & & & & & & & \\
\hline $\begin{array}{l}\text { Kurang mencari } \\
\text { informasi untuk } \\
\text { memecahkan } \\
\text { masalah (X2.9) }\end{array}$ & 43 & 12,7 & 133 & 39,2 & 94 & 27,7 & 55 & 16,2 & 14 & 4,1 & 2,60 \\
\hline
\end{tabular}

Sumber: Data Olahan (2018)

Tabel 4.2. menunjukkan rata-rata skor jawaban responden untuk variabel locus of control (LOC) eksternal adalah sebesar 2,99 dengan indikator tertinggi kurang memiliki inisiatif (X2.6) yang dicirikan persepsi karyawan mengenai individu dengan kecenderungan LOC eksternal akan membuat karyawan yang bersangkutan kurang memiliki inisiatif dalam bekerja karena melaksanakan pekerjaan sesuai dengan cara-cara umum yang telah lama digunakan. Hal ini bermakna positif karena dapat dideskripsikan bahwa mayoritas karyawan yang ada di perusahaan semen BUMN saat ini cenderung LOC internal dibandingkan LOC eksternal. Artinya secara rata-rata karyawan memiliki inisiatif dengan mencoba cara-cara yang lebih efektif dan efisien dalam melaksanakan pekerjaan. Indikator selanjutnya adalah mempunyai harapan bahwa ada sedikit korelasi antara usaha dan kesuksesan (X2.7) denganmayoritas responden memilih jawaban netral sebanyak 117 orang atau $34,5 \%$ yang dicirikan sebagian besar karyawan semen BUMN memiliki keraguan mengenai korelasi antara kerja keras dan usaha yang lebih menentukan pencapaian kesuksesan atau apakah nasib baik yang menjadi faktor determinan penentu kesuksesan individu karyawan.Ciri lain pada indikator ini adalah karyawan cenderung memiliki sikap dan keyakinan bahwa untuk mendapatkan pekerjaan dan karir yang bagus dibutuhkan usaha yang konsisten dan berkesinambungan misalnya melalui pelatihan atau kegiatan pengembangan diri lainnya. Sementara persepsi mengenai nasib baik atau buruk merupakan interpretasi yang dapat menyebabkan individu karyawan dengan kecenderungan LOC eksternal menjadi enggan untuk berusaha dan pesimis mencapai kesuksesan.

Indikator berikutnya kurang suka berusaha karena percaya bahwa faktor luarlah yang mengontrol (X2.8), dicirikan yakin bahwa karir yang mapan dengan penghasilan yang besar bukan dipengaruhi oleh adanya keberuntungan semata melainkan dari proses belajar dan pelatihan, usaha yang keras, dan kegigihan untuk mencapai kesuksesan. Temuan penelitian ini menunjukkan hal positif dan baik karena jika karyawan yang ada saat ini cenderung LOC eksternal, maka akan mengabaikan peluang untuk berprestasi dan bekerja keras memenuhi standar kompetensi dan kinerja yang ditetapkan perusahaan. Karyawan dengan LOC eksternal percaya bahwa keberuntungan mempengaruhi kesuksesan atau kegagalan pekerjaannya. Indikator terakhir adalah kurang mencari informasi untuk memecahkan masalah (X2.9), yang dicirikan persepsi individu terhadap tanggung jawab menyelesaikan masalah atau konflik yang terjadi di lingkungan kerja dibebankan pada rekan kerja. Mayoritas responden memilih jawaban tidak setuju sebanyak 133 orang atau $39,2 \%$. Hal ini bermakna baik dan positif 
karena dapat diidentifikasikan bahwa secara rata-rata karyawan di perusahaan semen BUMN dominan LOC internal yang percaya pada kemampuan dirinya untuk menyelesaikan setiap tantangan dan hambatan yang dihadapi dalam proses pelaksanaan pekerjaan. Temuan ini juga membuktikan bahwa secara umum karyawan memenuhi kompetensi teknis dengan kualifikasi analytical thinking dan kompetensi kepemimpinan dengan kualifikasi problem solving. Selain itu, tanggapan jawaban responden tertinggi selanjutnya adalah netral sebanyak 94 orang dengan persentase $27,7 \%$. Kemungkinan hal ini dipengaruhi oleh persepsi beberapa karyawan bahwa permasalahan atau konflik yang timbul dalam lingkungan kerja dapat diselesaikan sendiri maupun secara bersama berdasarkan pada karakteristik masalah yang ada.

Konstruksi LOC eksternal dikembangkan dari teori belajar sosial J.B. Rotter (Rotter, 1954, 1966). Menurut Rotter, pengendalian internal mengacu pada pengendalian diri tiap individu terkait persepsi atas pengaruh atau kontrolfaktor luar. Sedangkan mereka yang percaya bahwa keberhasilan kerja mereka dikendalikan oleh takdir, kesempatan, atau orang kuat lainnya dikatakan memiliki LOC eksternal. Konstruk ini dilihat sebagai harapan umum atau ekspektasi yang mendasari individu sehingga memiliki kecenderungan sikap dan keyakinan terhadap proses pencapaian keberhasilan kerja. Artinya individu dengan kecenderungan LOC eksternal dipandang sebagai harapan negatif untuk sukses sedangkan individu denganLOC internal memiliki harapan yang lebih positif(Biondo \& MacDonald, 1971).

Keberhasilan dan kegagalan karyawan dalam mencapai keberhasilan kerjaantara lain ditentukan oleh kemampuan, usaha, kesulitan tugas, dan nasib. Selanjutnya dinyatakan bahwa keempat unsur penyebab kegagalan dan keberhasilan tersebut digolongkan ke dalam dua dimensi kausal yaitu LOC internal dan LOC eksternal. Kemampuan dan usaha termasuk dimensi LOC internal sedangkan kesulitan tugas dan nasib termasuk LOC eksternal. Kemampuan merupakan unsur internal yang stabil dan bisa juga merupakan unsur internal yang tidak stabil atau dapat bervariasi, sedangkan kesulitan melaksanakan pekerjaan merupakan unsur eksternal yang tergolong stabil dan nasib termasuk unsur eksternal yang tidak stabil.

LOC dihubungkan dengan orientasi perilaku yang berhubungan positif dengan keberhasilan kerja ( $\mathrm{Ng}$, Sorensen, \& Eby, 2006). Persepsi ini merupakan salah satu prediktor penting yang secara umum mempengaruhi sikap dan keyakinan individu dalam mewujudkan keberhasilan kerja sesuai yang dipersyaratkan perusahaan. Tiap individu memiliki kecenderungan LOC yang berbeda antara satu dan lainnya, dimana kecenderungan tersebut secara langsung maupun tidak langsung berdampak pada cara kerja dan orientasi terhadap tujuan kerja dan keberhasilan kerja yang ingin dicapai. Penelitian ini juga menunjukkan bahwa ada beberapa aspek dari variabel LOC yang masih perlu mendapat perhatian seperti individu karyawan dalam kelas sosial ekonomi tertentu mewakili bagian dari sebuah sistem nilai di mana faktanya kelas sosial karyawan yang dimaksudkan dalam kajian ini tidak hanya mengenai status ekonomi, tetapi juga memiliki arti yang luas termasuk tingkat pendidikan, kebiasaan, pendapatan dan gaya hidup tiap individu karyawan. Pada dasarnya persepsi karyawan perusahaan semen BUMN untuk melakukan usaha-usaha yang dapat menyebabkan dirinya atau tim di unit kerjanya tergerak melakukan sesuatu karena ingin mencapai tujuan yang dikehendaki atau mendapat keberhasilan dan prestasi kerja yang diharapkan. Dalam proses pencapaian keberhasilan kerja, LOC merupakan faktor yang mempengaruhi karyawan untuk mewujudkan keberhasilan dirinya secara 
personal, unit kerjanya maupun perusahaan secara menyeluruh.

\section{SIMPULAN DAN SARAN}

Salah satu konsep penting yang
perlu
dikembangkan mengidentifikasi perubahan sikap dan perspektif karyawan adalah locus of control (LOC). Hasil temuan dalam penelitian ini menunjukkan bahwa ratarata karyawan semen BUMN memiliki kecenderungan LOC internal lebih tinggi dibandingkan LOC eksternal.

Pengenalan kepribadian karyawan melalui variabel locus of control sangat perlu dikaitkan dengan tujuan perubahan perusahaan agar memungkinkan pimpinan menempatkan karyawan pada tugas dan tanggung jawab yang sesuai dengan kepribadian masing-masing sehingga akan berdampak positif bukan hanya bagi karyawan yang bersangkutan dalam hal dorongan bekerja secara produktif dan pencapaian keberhasilan kerja yang tinggi namun juga bagi perusahaan. Selain itu, pada penelitian selanjutnya aspek pengenalan kepribadian tiap individu karyawan perlu dipertimbangkan khususnya terkait locus of control.

\section{DAFTAR RUJUKAN}

Anderson, C. R. (1977). Locus of control, coping behaviors, and performance in a stress setting: a longitudinal study. The Journal of Applied Psychology, 62(4), $\quad$ 446-451. https://doi.org/10.5465/AMBPP.1976 .4975566

Anderson, C. R., \& Schneier, C. E. (1978). Locus of Control, Leader Behavior and LeaderPerformance Among Management Students. Academy of Management Journal, 21(4), 690698. https://doi.org/10.2307/255709
April, K. A., Dharani, B., \& Peters, K. (2012). Impact of locus of control expectancy on level of well-being. Review of European Studies, 4(2), 124-137. https://doi.org/10.5539/res.v4n2p124

April, K., Dharani, B., \& Peters, K. (2011). Leader career success \& locus of control expectancy. Academy of Taiwan Business Management Review, 7(3), 28-40. Retrieved from http://www.ashridge.org.uk/website/I C.nsf/8DCB367CFC480F248025797 A00541C51/\$file/LeaderCareerSucce ss\&LocusOfControlExpectancy.pdf

Barbuto, J. E., Fritz, S. M., \& Marx, D. (2002). A field examination of two measures of work motivation as predictors of leaders' influence tactics. Journal of Social Psychology. https://doi.org/10.1080/00224540209 603921

Biondo, J., \& MacDonald, A. P. (1971). Internal-external locus of control and response to influence attempts. Journal of Personality, 39(3), 407419. https://doi.org/10.1111/j.14676494.1971.tb00051.x

Boam R, Sparrow P. (1992). Designing and Achieving Competency: A Competency Based Approach. Published by McGraw-Hill Book Company, Maidenhead. ISBN 10: 0077075722/ ISBN 13: 9780077075729

Chen, J., \& Wang, L. (2007). Locus of control and the three components of commitment to change. Personality and Individual Differences, 42(3), 503-512. https://doi.org/10.1016/j.paid.2006.07 .025 
Cobb-Clark, D. (2015). Locus of control and the labor market. IZA Journal of Labor Economics, 4(1), 3 https://doi.org/10.1186/s40172-0140017-x

CONNOLLY, S. G. (1980). Changing Expectancies: A Counseling Model Based on Locus of Control. The Personnel and Guidance Journal, 59(3), 176-180. https://doi.org/10.1002/j.21644918.1980.tb00525.x

Lee, H. W. (2013). Locus of control, socialization and organizational identification. Actual Problems of Economics, 146 (8), 322-328. https://doi.org/10.1108/MD-11-20120814

Marks, L. I. (1998). Deconstructing locus of control: Implications for practitioners. Journal of Counseling and Development.

Martin, R., Thomas, G., Charles, K., Epitropaki, O., \& McNamara, R. (2005). The role of leader-member exchanges in mediating the relationship between locus of control and work reactions. Journal of Occupational and Organizational Psychology, 78(1), 141-147. https://doi.org/10.1348/096317904X2 3763

Ng, T. W. H., Sorensen, K. L., \& Eby, L. T. (2006). Locus of control at work: A meta-analysis. Journal of Organizational Behavior, 27(8), 1057-1087.

https://doi.org/10.1002/job.416

Pannells, T. C., \& Claxton, A. F. (2008). Happiness, Creative Ideation, and Locus of Control. Creativity Research Journal, 20 (1), 67-71. https://doi.org/10.1080/10400410701 842029

Piatek, R., \& Pinger, P. (2010). Maintaining (Locus of) Control? Assessing the Impact of Locus of Control on Education Decisions and Wages. IZA Discussion Paper Series, (5289), 52.

Ryon, H. S., \& Gleason, M. E. J. (2014). The Role of Locus of Control in Daily Life. Personality and Social Psychology Bulletin, 40 (1), 121-131.

https://doi.org/10.1177/01461672135 07087

Schnitzlein, D. D., \& Stephani, J. (2016). Locus of Control and low-wage mobility. Journal of Economic Psychology, 53. https://doi.org/10.1016/j.joep.2016.01 .004

Spector, P. E. (1982). Behavior in organizations as a function of employee's locus of control. Psychological Bulletin, 91(3), 482497. https://doi.org/10.1037/00332909.91.3.482

Wang, Q., Bowling, N. A., \& Eschleman, K. J. (2010). A meta-analytic examination of work and general locus of control. Journal of Applied Psychology, 95(4), 761-768. https://doi.org/10.1037/a0017707

Zhou, W., Guan, Y., Xin, L., Mak, M. C. K., \& Deng, Y. (2016). Career success criteria and locus of control as indicators of adaptive readiness in the career adaptation model. Journal of Vocational Behavior, 94. https://doi.org/10.1016/j.jvb.2016.02. 015 